\title{
Evaluation and differential expression of genes conferring drought tolerance in selected maize genotypes in the Morogoro Region of Tanzania
}

\author{
Gertrude G. Kanyairita ${ }^{1}$, Desmond G. Mortley ${ }^{2}$, George T. Muhamba ${ }^{3}$, Marceline Egnin ${ }^{2}$ \\ and Conrad K. Bonsi ${ }^{2}$ \\ ${ }^{1}$ Tropical Pesticide Research Institute, P. O. Box 3024, Arusha, Tanzania. \\ ${ }^{2}$ George Washington Carver Agricultural Experiment Station, Tuskegee University, Tuskegee AL 36088, USA. \\ ${ }^{3}$ Crop Science Department, Sokoine University of Agriculture, Morogoro, Tanzania.
}

Received 18 May, 2018; Accepted 26 June, 2018

\begin{abstract}
Experiments were conducted at Sokoine University of Agriculture in Morogoro, Tanzania to assess the growth performance and grain yield of ten maize cultivars under well-watered and water stressed conditions. The ten cultivars (CML 444, CML395, CML539, WE 4107, WE 2112, WE 3102, WE 4112 and WE 4116) obtained from Water Efficiency Maize for Africa (WEMA) project and two local market cultivars ('STAHA' and 'TMV1') were grown in a Randomized Complete Block design with a $10 \times 3$ factorial treatment arrangement and three replications. The three drought stress treatments were 50,75 or $100 \%$ of field capacity with $10 \mathrm{kpa}$ (equivalent to field capacity) and $30 \mathrm{kpa}$ (drought) using tensiometers. Drought stress was initiated at vegetative stage (three weeks after emergence) for thirty days and flowering stage (one week before to two weeks after flowering). Plant height, stem diameter, leaf length, leaf width and chlorophyll content were measured at weekly intervals from two weeks after planting to maturity. Days to anthesis and silking were used to calculate Anthesis-Silking Interval (ASI) and kernel dry mass were recorded at harvest. Vegetative growth responses were not affected by water stress, but plant height and leaf chlorophyll content tended to decrease, while ASI ranging from 5.2 to 11.1 days and kernel dry mass decreased with increased drought stress. Dry kernel weight was significantly greater among five of the cultivars designated drought tolerant and the lowest in the two drought susceptible cultivars. Drought tolerant genes were expressed at different levels and only a few cultivars expressed all three genes at the vegetative and flowering stages. Thus, vegetative response of maize to drought stress varied based on cultivars. However, it appears that drought stress exerted more impacts on reproductive processes compared to vegetative.
\end{abstract}

Key words: Cultivars, drought, genotypes, grain yield, growth performance, hybrids.

\section{INTRODUCTION}

Maize (Zea mays L.) is commonly grown worldwide and used as food (animals and humans) and as transportation fuel in developed countries. In Tanzania, maize is the main staple as well as cash crop and is produced on approximately 4.0 million ha in almost all of the four official agro ecological zones by small or limited resource 
farmers compared to rice, wheat, millet and sorghum and is their main source of income (DTMA, 2014). Maize contributes about 60 and $30 \%$ of dietary and utilizable protein, respectively (DMTA, 2014; Lyimo, et al., 2001).

Despite the increase in land acreage, production is still very low averaging $1.37 \mathrm{t} \mathrm{ha}^{-1}$ grain yield due to limited moisture, while $5 \mathrm{t} \mathrm{ha}^{-1}$ are required to satisfy the food demand (DTMA, 2014). Due to a fast growing population, it is estimated that maize production must increase by 3.0 to $3.5 \%$ annually to satisfy demand, which exceeded the $2.0 \%$ growth rate over the past two decades (Lyimo et al., 2001).

Climate change has caused a disruption in rainfall patterns and thus no longer a reliable source of moisture especially at flowering, pollination and embryo development stages to produce a harvestable crop. For example, most of the agro ecological regions (Magehema et al., 2014), that receive rains twice per year are now either receiving it once or only for short periods despite high maize production. Maize requires high amounts of moisture to produce a complete crop especially at tasseling, silking and blister kernel stages (Xu et al., 2014). The southern highlands receive the highest percent distribution in terms of area and amount of maize production of $26 \%$, followed by Lake, Eastern, Northern, Western, Southern and Central zones of 25, 13, 12, 10, 8 and $6 \%$, respectively (DMTA, 2014).

Drought is the most limiting factor for maize production especially if deficit occurs at grain filling and dough stages and is first among the criteria considered by farmers when selecting varieties (Lyimo et al., 2001). In maize production, moisture requirements fluctuate based on growth stages with greatest requirements. There are few drought tolerant maize varieties in the country that were developed through other on-going projects. These varieties have been used in some ecological zones although their genetic diversity is not well known.

Drought stress greatly reduces net photosynthesis rates in plants (Mafakheri et al., 2010), and as the intensity of drought stress increases, the photosynthetic rate decreases even further, eventually reducing yield (Liu et al., 2012). The synthesis of chlorophyll $a$ and $b$ is inhibited as well as a reduction in the content of chlorophyll $\mathrm{a}$ and $\mathrm{b}$ binding proteins, leading to a decline in the light-harvesting pigment proteins associated with photosystem II (Farooq et al., 2009). Plants under water deficit reduce transpirational water losses by reducing stomatal conductance causing partial or complete closure (Ghannoum, 2008). Stomata closure reduces $\mathrm{CO}_{2}$ uptake thus reducing photosynthetic rates, transpirational cooling, water and nutrient uptake (Lu et al., 2011).

Kamara et al. (2003) revealed that water deficit imposed at various developmental stages of maize reduced total biomass accumulation at silking by $37 \%$, at grain filling by $34 \%$ and at maturity by $21 \%$. Therefore, moisture stress can cause delay in silk emergence, hence increasing the anthesis-silking interval (ASI; the time in days between pollen shed and silk emergence) (Aylor et al., 2003) or silks may desiccate and become non-receptive to pollen germination.

Delay in silk emergence is connected to a delay in silk elongation, a process, which takes place through cell division and expansion. Water deficit affects cell expansion, which minimizes silk elongation rates, sometimes to zero, which in turn affects ASI (Monneveux et al., 2006). Longer ASI causes asynchronies in maize flowering that result in incomplete pollination and kernel set, hence yielding losses. The first two weeks after silking are most critical for fertilization and embryo development both of which require high amounts of moisture. Water stress at this stage causes embryo abortion which in turn affects final grain yield (HayanoKanashiro et al., 2009; Wei et al., 2009), reduces silk length, inhibits embryo development after pollination and reduces ear size and number of kernels to be fertilized (Farooq et al., 2009).

There are a set of drought tolerant genes that are known to control physiological and biochemical processes of plants during water stress and breeding practices such as inbreeding or breeding open pollinated varieties (OPVs) reduce genetic diversity among plant materials. Current research shows that most of maize varieties developed in Africa are OPVs and the genetic features of most of them are not known.

The objectives of this study were (1) to compare water use, grain yield and growth responses of ten maize cultivars under well-watered and water stressed conditions and (2) to assess the expression of drought tolerant genes at both vegetative and flowering stage to identify tolerance or susceptibility.

\section{MATERIALS AND METHODS}

Greenhouse experiments were conducted in a Randomized Complete Block Design with a $10 \times 3$ factorial treatment arrangement and three replications at Sokoine University of Agriculture (SUA) in Morogoro, Tanzania. The treatment combinations were moisture at 100 (equivalent to field capacity), 75 and $50 \%$, respectively, of field capacity and ten maize hybrid varieties eight of which ('CML444', 'CML395', 'CML539', 'WE4107', 'WE2112', 'WE3102', 'WE4112' and WE 4116) were obtained from the Water Efficiency Maize for Africa (WEMA) project located at the llonga Agricultural Research Institute-Morogoro, Tanzania and are classified as being drought tolerant. The remaining two hybrid maize hybrid varieties, STAHA and TMV1, are regularly grown by local farmers and are classified

*Corresponding author. E-mail: dmortley@tuskegee.edu.

Author(s) agree that this article remain permanently open access under the terms of the Creative Commons Attribution License 4.0 International License 
as being drought susceptible.

\section{Planting and treatment initiation}

The oven dry weight method was used to determine percent soil moisture that approximates field capacity, beginning with determining the gravimetric moisture content (Gardner, 1986). A $1000 \mathrm{ml}$ graduated cylinder with a hole drilled in the bottom, to allow air to escape when water was added was filled with a random subsample of air-dried soil, which was leveled to a similar consistency. The surface of the soil was covered with paper towel and $100 \mathrm{ml}$ of water were poured slowly onto the surface to obtain an even distribution through the column. The cylinder was covered to avoid evaporation and allowed to equilibrate stand for $24 \mathrm{~h}$ following which there was a sharp line where the water stopped moving in the soil column. Triplicate soil samples were collected from the cylinder about $5 \mathrm{~cm}$ above the wetting front and dried at $100^{\circ} \mathrm{C}$ to a constant weight after which dry weight was recorded and gravimetric moisture fraction was determined using the fresh to dry weight ratio. This information was used to determine the amount of oven-dry soil per pot, and watering to field capacity $(1 \mathrm{~L})$ was done by weighing the pots.

Ten liters pots were filled with $10 \mathrm{~kg}$ of air-dried soil into which diammonium phosphate $\left(\left(\mathrm{NH}_{4}\right)_{2} \mathrm{HPO}_{4} ; 18-46-0\right)$ fertilizer was thoroughly incorporated based on soil test recommendations for the Morogoro region. The drought stress treatments of 100 (field capacity), 75 and $50 \%$ of field capacity were initiated at vegetative stage (three weeks after emergence) for thirty days watered again for one week, and then imposed one week before flowering stage to two weeks after. Field capacity moisture (well-watered) was kept at $10 \mathrm{kpa}$ and drought stress kept at $30 \mathrm{kpa}$ using tensiometers.

Phenological measurements taken included plant height, stem diameter, leaf length, width and chlorophyll content. Leaf chlorophyll content was measured for fully expanded leaves using an Apogee CCM 200+ chlorophyll content meter (Apogee Instruments, Logan UT, USA) beginning one week after emergence to harvest, while leaf length and width were assessed on one leaf per plant up to maximum growth (no further increases in either length or width), corresponding to about six to eight weeks after emergence.

\section{Gene expression profiling}

Mature disease free maize leaves were collected at the early vegetative and flowering stages of plant development from all ten genotypes cleaned with RNAlater and stored at $-80^{\circ} \mathrm{C}$. RNA was isolated according to the CTAB method (Hilario and MacKay, 2007). A $0.3 \mathrm{~g}$ leaf sample was ground manually using a mortar and pestle in $300 \mu \mathrm{l}$ of buffer followed by an additional $700 \mu \mathrm{l}$ and further ground and then centrifuged at $12000 \mathrm{~g}$ for $5 \mathrm{~min}$ at $4^{\circ} \mathrm{C}$. The supernatant was transferred to new Eppendorf tubes, containing $200 \mu \mathrm{l}$ of acid water to which extracted chloroform was added and shaken vigorously for $15 \mathrm{~s}$ and incubated at room temperature for 3 $\min$. The sample was centrifuged at $12000 \mathrm{~g}$ for $15 \mathrm{~min}$ at $4^{\circ} \mathrm{C}$, and the upper aqueous phase transferred to a new tube followed by the addition of $0.5 \mathrm{ml}$ of isopropanol, mixed, and incubated at room temperature for $10 \mathrm{~min}$, and centrifuged at $12000 \mathrm{~g}$ for $10 \mathrm{~min}$ at $4^{\circ} \mathrm{C}$. The supernatant was discarded and $1.5 \mathrm{ml}$ of $75 \%$ ethanol was added to the pellet, vortexed briefly and centrifuged at $12000 \mathrm{~g}$ for $5 \mathrm{~min}$ at $4^{\circ} \mathrm{C}$. The supernatant was discarded and the pellets allowed to dry after which they were dissolved in $20 \mu$ of RNase free water, briefly centrifuged and then transferred to a new tube. The quality and quantity of total RNA was checked using Nano drop and native $1 \%$ agarose gel in TBE.
Riverse transcriptase polymerase chain reaction (RT-PCR) and real time PCR (qPCR)

Total cDNA was synthesized from total RNA utilizing Notl-OligodT bifunctional primer with Access Quick RT-PCR system (Promega Corp., Fitchburg $\mathrm{WI}$ ) as per the manufacture's guidelines. Total CDNA was utilized in downstream quantitative expression profilings in RT-PCR with SYBR-Green. Primers utilized for expression profiling included ProDH, UBQ7, Ubiquitin, P5CS, P5CR and Maize actin (internal reference). The conditions for amplifications were an initial denaturation at $95^{\circ} \mathrm{C}$ for $2 \mathrm{~min}$, a final denaturation at $95^{\circ} \mathrm{Cfor}$ $30 \mathrm{~s}$, annealing at $53^{\circ} \mathrm{C}$ for $30 \mathrm{~s}$ for $(\mathrm{ProDH})$ and $50^{\circ} \mathrm{C}$ for other primers, extension at $72^{\circ} \mathrm{C}$ for $30 \mathrm{~s}$, a final extension at $72^{\circ} \mathrm{C}$ for 5 min and a $4^{\circ} \mathrm{C}$ hold. Of the five primers, only ProDH, UBQ7 and Ubiquitin showed good amplification bands and therefore they were used for further qPCR analysis. Quantitative qPCR was performed using a Thermo scientific maxima SYBR Green/Fluorescein qPCR master mix $(2 x)$ as per the manufacturer's instructions.

\section{RESULTS AND DISCUSSION}

\section{Biomass production}

The analysis of variance to cultivar, drought stress, and the cultivarxdrought stress interactions for plant height, stem diameter, leaf length and width, chlorophyll content, anthesis-silking interval (ASI) and dry seed weight of the ten maize varieties are shown in Table 1. Drought stress had no significant impact on plant height or stem diameter, but enhanced chlorophyll content, ASI and weight of dry kernels, while cultivar significantly influenced all variables.

While the main effect of drought stress on plant height was not significant, certain trends were evident. Plant height and leaf chlorophyll content tended to decrease with increased water stress while ASI and dry seed weight decreased significantly with increased drought stress (Table 2).

For cultivar main effects, hybrids 'TMV1' and 'STAHA' responded differently to drought stress as compared to the drought tolerant hybrids (Table 3). 'STAHA' had bigger stems than all other cultivars studied and leaf chlorophyll concentration was similar for 'STAHA', 'TMV1', 'WE4116', 'WE4107' and 'WE210'.

'TMV1' and 'STAHA', the regular hybrids on the market were decidedly taller than the other cultivars while the other eight cultivars had similar heights (Table 3 ). The ASI ranged from 5.2 days to 11.1 days, with 'CML444' and 'WE4107' having the shortest while, 'WE4116' and 'WE4107' had the longest but similar to that of 'CML539', 'WE3102', 'WE4112', 'TMV1' and 'STAHA'. Dry seed weight was significantly greater among five of the cultivars designated drought tolerant and the lowest in the two drought susceptible cultivars.

\section{Gene expression profiling}

For expression levels determined at the vegetative stage (Figure 1), ProDH gene was expressed significantly in all 
Table 1. Statistical significance from analysis of variance (ANOVA) of cultivar, drought, time (weeks) and their respective interactions for plant height, stem diameter, chlorophyll content and dry seed weight of maize (Zea mays L.).

\begin{tabular}{|c|c|c|c|c|c|c|}
\hline $\begin{array}{l}\text { Source of } \\
\text { variation }\end{array}$ & df & $\begin{array}{l}\text { Plant diameter } \\
\text { (cm) }\end{array}$ & $\begin{array}{l}\text { Stem diameter } \\
(\mathrm{cm})\end{array}$ & $\begin{array}{c}\text { Chlorophyll content } \\
\left(\mu \mathrm{molm}^{-2}\right)\end{array}$ & $\begin{array}{l}\text { Anthesis silking } \\
\text { interval (days) }\end{array}$ & $\begin{array}{c}\text { Dry seed } \\
\text { weight }\end{array}$ \\
\hline Drought (DR) & 2 & NS & NS & * & $\star * *$ & $\star \star$ \\
\hline Cultivar & 9 & $* * *$ & *** & *** & $* * *$ & * \\
\hline Cultivar*DR & 18 & NS & NS & NS & NS & * \\
\hline
\end{tabular}

All biomass and phenological data are the mean of three replications of one plant each. Plant height and stem diameter are expressed in centimeters $(\mathrm{cm})$, chlorophyll content as micro mole per square meter per second, and dry seed weight as grams per plant. Anthesis silking interval is the number

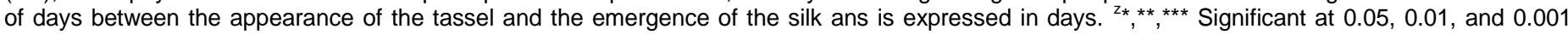
levels of probability, respectively.

Table 2. The main effect of drought stress on plant height, chlorophyll content, anthesis-silking interval (ASI), plant height and dry seed weight of ten maize cultivars. ${ }^{2}$

\begin{tabular}{ccccc}
\hline $\begin{array}{c}\text { Drought plant stress } \\
(\%)\end{array}$ & Plant height $(\mathbf{c m})$ & $\begin{array}{c}\text { Chlorophyll content } \\
\left(\mu \mathrm{mol} \mathrm{m}^{-2}\right)\end{array}$ & $\begin{array}{c}\text { Anthesis silking interval } \\
(\mathbf{d a y s})\end{array}$ & $\begin{array}{c}\text { Dry seed weight } \\
\left.\left(\mathbf{g} \text { plant }^{-1}\right)\right)\end{array}$ \\
\hline $50^{\mathrm{x}}$ & $76.8^{\mathrm{a}}$ & $19.9^{\mathrm{ab}}$ & $11.4^{\mathrm{a}}$ & $13.3^{\mathrm{b}}$ \\
75 & $78.6^{\mathrm{a}}$ & $19.6^{\mathrm{b}}$ & $9.2^{\mathrm{b}}$ & $13.3^{\mathrm{b}}$ \\
100 & $80.7^{\mathrm{a}}$ & $21.1^{\mathrm{a}}$ & $6.7^{\mathrm{c}}$ & $29.5^{\mathrm{a}}$ \\
\hline
\end{tabular}

All biomass and phenological data are the mean of three replications of one plant each. Plant height and stem diameter are expressed in centimeters $(\mathrm{cm})$, chlorophyll content as micro mole per square meter per second, and dry seed weight as grams per plant. Anthesis silking interval is the number of days between the appearance of the tassel and the emergence of the silk ans is expressed in days. ${ }^{2}$ Means within a column followed by the same letter are not significantly different $($ LSD $P<0.05)$.

Table 3. The main effect of cultivar on plant height, stem diameter, anthesis silking interval (ASI), chlorophyll content and total seed weight of ten maize cultivars subjected to drought stress. ${ }^{2}$

\begin{tabular}{|c|c|c|c|c|c|}
\hline Cultivar & $\begin{array}{c}\text { Plant } \\
\text { height (cm) }\end{array}$ & $\begin{array}{c}\text { Height } \\
\text { diameter }(\mathrm{cm})\end{array}$ & $\begin{array}{c}\text { Anthesis-silking } \\
\text { interval (days) }\end{array}$ & $\begin{array}{c}\text { Chlorophyll content } \\
\left.(\mu \mathrm{molm})^{-2}\right)\end{array}$ & $\begin{array}{l}\text { Dry kernel weight } \\
\left(\mathrm{g} \mathrm{plant}^{-1}\right)\end{array}$ \\
\hline CML $444^{x}$ & $75.1^{\text {cd }}$ & $3.8^{\mathrm{cd}}$ & $5.2^{\mathrm{c}}$ & $19.6^{\text {cde }}$ & $24.2^{\mathrm{ab}}$ \\
\hline CML 395 & $68.7^{\text {de }}$ & $4.3^{b}$ & $7.3^{\mathrm{bc}}$ & $20.1^{\mathrm{bcd}}$ & $26.2^{\mathrm{a}}$ \\
\hline CML 539 & $58.9^{\mathrm{e}}$ & $3.2^{\mathrm{e}}$ & $8.4^{\mathrm{abc}}$ & $18.4^{\mathrm{de}}$ & $17.3^{\mathrm{b}}$ \\
\hline WE 4107 & $82.5^{\mathrm{bc}}$ & $3.8^{\mathrm{cd}}$ & $11.1^{\mathrm{a}}$ & $21.1^{\mathrm{abc}}$ & $29.6^{\mathrm{a}}$ \\
\hline WE 2112 & $78.8^{\mathrm{cd}}$ & $3.7^{\mathrm{d}}$ & $8.0^{\mathrm{bc}}$ & $21.3^{\mathrm{abc}}$ & $27.5^{\mathrm{a}}$ \\
\hline WE 3102 & $74.6^{\mathrm{cd}}$ & $3.8^{\mathrm{cd}}$ & $8.3^{\mathrm{abc}}$ & $18.8^{\text {cde }}$ & $27.2^{\mathrm{a}}$ \\
\hline WE 4112 & $77.1^{\mathrm{cd}}$ & $3.4^{\mathrm{de}}$ & $10.2^{\mathrm{ab}}$ & $17.5^{\mathrm{e}}$ & $3.9^{c}$ \\
\hline WE 4116 & $81.3^{\mathrm{bc}}$ & $4.2^{b c}$ & $11.1^{\mathrm{a}}$ & $20.8^{\mathrm{abcd}}$ & $26.6^{\mathrm{a}}$ \\
\hline TMV1 & $91.9^{\mathrm{ab}}$ & $4.6^{\mathrm{b}}$ & $10.9^{\mathrm{ab}}$ & $21.4^{\mathrm{ab}}$ & $4.8^{\mathrm{C}}$ \\
\hline STAHA & $98.3^{\mathrm{a}}$ & $5.2^{\mathrm{a}}$ & $10.7^{\mathrm{ab}}$ & $23.1^{\mathrm{a}}$ & $6.8^{\mathrm{c}}$ \\
\hline
\end{tabular}

${ }^{\mathrm{X}} \mathrm{All}$ biomass and phenological data are the mean of three replications of one plant each. Plant height and stem diameter are expressed in centimeters $(\mathrm{cm})$, chlorophyll content as micro mole per square meter per second, and dry seed weight as grams per plant. Anthesis silking interval is the number of days between the appearance of the tassel and the emergence of the silk ans is expressed in days. ${ }^{z}$ Means within a column followed by the same letter are not significantly different (LSD $\mathrm{P}<0.05)$.

cultivars except in 'STAHA' $(\mathrm{J})$. The highest expression was observed in 'CML395' (B) and 'CML444' (A) and the lowest in 'TMV1' (I). The UBQ7 gene was expressed practically in all cultivars except in 'STAHA'. The highest UBQ7 gene expression was observed in 'WE4116' (H) and 'WE2112' (E), while the lowest expression was in'WE3102' (F). The Ubiquitin gene was highly expressed in 'WE3102' (F) and lower in 'CML395'.

At flowering, UBQ7 expression was significantly higher in all cultivars except in 'STAHA (J) that had no 


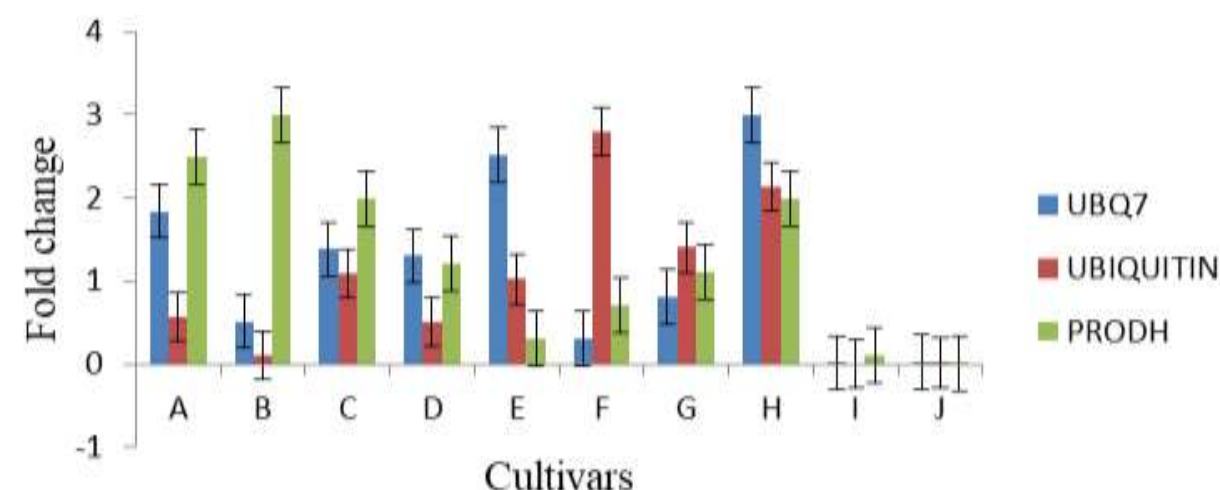

Figure 1. Differential expression of ubq7, ubiquitin and prodh genes in ten maize varieties sampled at vegetative (V6) stage. The relative quantification of gene expression is based on 2 $\triangle \triangle C T$ method using maize actin as a reference gene. ${ }^{\mathrm{Z}} \mathrm{A}-\mathrm{H}$ represents cultivars 'CML444', 'CML395', 'CML539', 'WE4107', 'WE2112', 'WE3102', 'WE4112', 'WE 4116, 'STAHA' and 'TMV1', respectively.

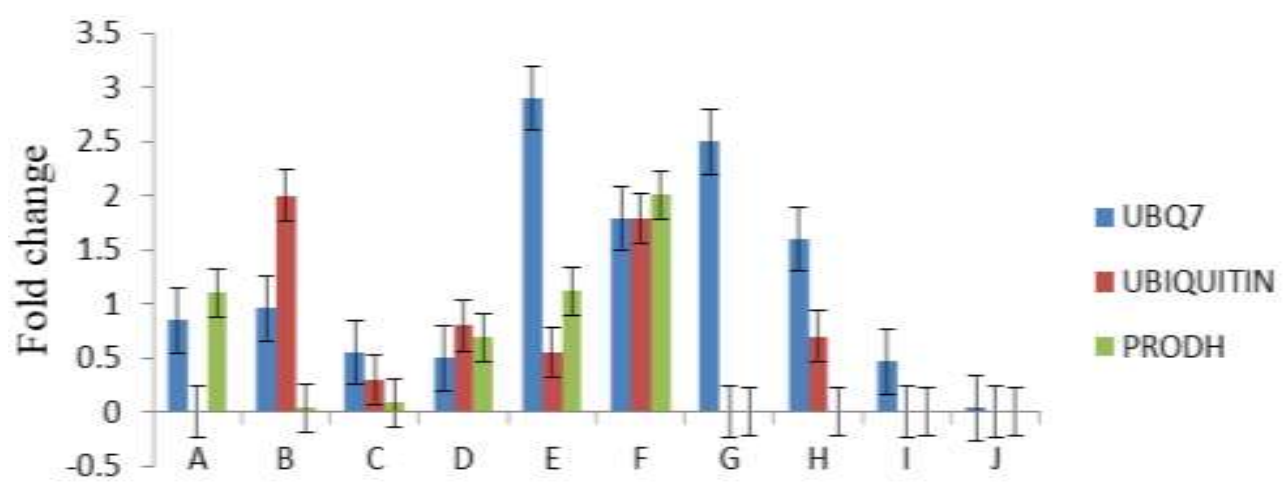

Cultivars

Figure 2. Differential expression of ubq7, ubiquitin and prodh genes on ten maize varieties sampled at flowering stage. The relative quantification of gene expression is based on $2^{-\Delta \Delta C T}$ method using maize actin as a reference gene. ' $\mathrm{A}-\mathrm{H}$ represents cultivars 'CML444', 'CML395', 'CML539', 'WE4107', 'WE2112', 'WE3102', 'WE4112', 'WE 4116, 'STAHA' and 'TMV1', respectively.

significant expression of any gene (Figure 2). Ubiquitin was not expressed in cultivars 'CML444' (A), 'WE4112' (G), 'TMV1' (I) or 'STAHA' (J), respectively. ProDH was also expressed in few cultivars, the highest expression being in 'WE3102' (F) with a fold change of 2.5. All three genes were significantly expressed in cultivars 'CML539'(C), 'WE4107' (D), 'WE2112' (E), and WE3102 $(\mathrm{F})$, while cultivars 'CML395' (B) and 'WE4116' (H) expressed Ubiquitin and UBQ7, 'CML444' (A) expressed UBQ7 and ProDH, 'WE4112' (G) and 'TMV1' (I) expressed $U B Q 7$ only.

These results showed that the response of maize genotypes to drought is cultivar dependent. Water stress reduced plant height and leaf width as plants under wellwatered conditions were decidedly taller with broader leaves than water stressed plants and the plant height decreased with the increase in water stress. Lack of adequate moisture reduces growth in the meristematic tissue hence a slow rate of plant elongation (Hussain et al., 2008). The reduction in leaf width can also impact photosynthetic activity as a reduction in leaf area means that there is less surface area to trap light for photosynthesis. The opposite was true for stem diameter (stem expansion) as with a higher rate of water stress, plant expansion was not significantly affected, as was leaf length. Chlorophyll content varied with cultivar and tended to be higher under reduced drought stress. Hybrids cultivars 'TMV1' and 'STAHA' responded differently to drought stress as compared to the drought tolerant hybrids.

Drought stress did not reduce any of the traits studied at the vegetative stage since less moisture is required at 
this stage but more variation was observed among cultivars rather than among the levels of stress. Drought stress caused an increase ASI in that a shorter ASI was observed with well-watered plants and a longer ASI at $50 \%$ drought stress. The average grain yield for drought tolerant genotypes was higher despite the longer ASI of some cultivars than the regular hybrids, which are drought susceptible.

Stress during the pollination and silking period often reduces yield potential of maize and ASI is one of the best indicators. According to Avan et al. (2008), silk development consists of four phases: (1) cell division and tissue expansion occurred together uniformly all along the silk; (2) cell division progressively ceases from tip to base, while expansion remains spatially uniform including during the phase, (3) after the cessation of cell division, and (4) as the silk emerges from the husks, expansion ceases in the emerged portion, probably because of direct evaporative demand, while the relative growth rate progressively decreased in the enclosed part. They indicated that water deficits can reduce the rate of tissue expansion and cell division resulting in delayed silk emergence. This could partly explain the longer ASI observed under drought stress in our study, especially in phase 3 of development, the duration of the time between the end of cell division and the arrest of cell growth in silk apex, corresponded to the anthesis-silking interval used by breeders to characterize the response of cultivars to stress.

Drought tolerant genes are expressed to enable metabolic activities of the plant in order to complete its life cycle when there is water stress. Maize requires more water at flowering through the grain filling stage than at any other growth stage (Kranz et al., 2008). Drought stress in this study was imposed at vegetative (V6) stage and at flowering (tasseling to silking stage). At flowering, the UBQ7 gene was up regulated in cultivars 'CML395', 'WE2112', 'WE3102', 'WE4112' and 'STAHA', ubiquitin gene was up regulated in cultivars 'CML395' and 'WE4107', while ProDH gene was up regulated in cultivars 'WE2112' and 'WE3102'. Therefore, cultivars with genes up regulated at flowering may be considered to have higher tolerance levels as compared to those that were down regulated although this inference would have to be confirmed in further studies, in which a greater number of drought tolerant genes may be considered and in which plants may be subjected to greater levels of stress.

At vegetative stage, all genes studied were highly expressed although expression varied with cultivars. Gene expression at flowering showed a down regulation of some genes that were highly expressed at the vegetative stage. The down regulation of drought tolerant genes probably affects photosynthesis (Photosystems I and II) and on energy metabolism processes both at vegetative and reproductive stages (Batlang et al., 2014).

Of the ten cultivars, only in three, namely 'WE4107', 'WE3102' and 'WE2112', was expression of these genes high both at vegetative and flowering stages. This suggests that these cultivars may be considered more drought tolerant than others in this study.

Genetic diversity determinations showed that cultivars 'WE4107' and 'WE2112' were quite similar with a similarity coefficient of 1 , while 'WE3102' was marginally different from the other two with a similarity coefficient of 0.91 on both cultivars.

\section{Conclusion}

Drought tolerant and susceptible maize cultivars were used to assess growth, development and grain yield, drought gene expression level and genetic diversity. Drought had no significant effect on vegetative growth but exerted significant impacts on ASI and grain yield. Drought tolerant genes were expressed at different levels and only a few cultivars expressed all three genes at the vegetative and flowering stages. These genes were mostly down regulated at flowering than at the vegetative stage. Therefore, based on a short ASI, high dry mass of kernels and drought gene expression at both vegetative and flowering stages, cultivars 'WE2112', 'WE3102' and 'WE4107' appeared to be tolerant of the drought stress levels evaluated in this study. Thus, these cultivars which have shown a degree of drought tolerance, could be tested again through on-farm field trials in regions of the country where drought is severe, followed by differential gene expression using many other drought tolerant genes which were not involved in this study, and could form the basis for developing other drought tolerant varieties.

\section{CONFLICT OF INTERESTS}

The authors have not declared any conflict of interests.

\section{ACKNOWLEDGEMENTS}

Contribution of the Washington Carver Agricultural Experiment Station, Tuskegee University is acknowledged. This research was supported by funds from Innovative Agricultural Research Initiative, USAID.

\section{REFERENCES}

Avan AH, Tardieu F, Turc O (2008). Drought-induced changes in anthesis-silking interval are related to silk expansion: a spatiotemporal growth analysis in maize plants subjected to soil water deficits. Plant, Cell and Environment 31:1349-1361.

Aylor DE, Schultes NP, Shields EJ (2003). An aerobiological framework for assessing cross-pollination in maize. Agriculture Forest Meteorology 119:111-129.

Batlang U, Madana MR, Ambavaram A, Pereira A (2014). Drought responsive genes and their functional terms identified by GS FLX Pyrosequencing in maize. Maydica Electronic Publication. Kindly Mydica 59:306-314. 
Drought-tolerant maize for Africa (DTMA) (2014). A quarterly bulletin of the drought tolerant maize for Africa project. http://dtma.cimmyt.org/index.php/publications/doc_details/188-dtmaize-a-quarterly-bulletin-of-the-drought-tolerant-maize-for-africaproject

Farooq M, Wahid A, Kabayoshi N, Fujita D, Basra SMA (2009). Plant drought stress: effects, mechanisms and management. Agronomy for sustainable development, Springer Verlag (Germany) 29(1):185-212.

Gardner WH (1986). Water content. Chap. 21 in Klute, A., ed. Methods of soil analysis. Part 1. Physical and mineralogical methods. 2nd Ed. Soil Science Society of America, Inc. Madison, Wisconsin.

Ghannoum $\mathrm{O}$ (2008). $\mathrm{C}_{4}$ photosynthesis and water stress. Annals Botany doi:10.1093/aob/mcn093, http://www.aob.oxfordjournal.org. Retrieved December 28, 2014.

Hayano-Kanashiro C, Calderon-Vazquez C, Ibarra-Laclette E, HerreraEstrella L, Simpson J (2009). Analysis of gene expression and physiological responses in three mexican landraces under drought stress and recovery irrigation. PLoS One 4:1-19.

Hilario MM, MacKay JF (2007). Protocol for nucleic acid analysis by noradioactive probes $2^{\text {nd }}$ edition. Humana Press Inc. New York, NY.

Hussain M, Malik MA, Farooq M, Ashraf MY, Cheema MA (2008). Improving drought tolerance by exogenous application of glycinebetaine and salicylic acid in sunflower. Journal Agronomy Crop Science 194:193-199.

Kamara AY, Menkir A, Badu-apraku B, Ibikunle O (2003). The influence of drought stress on growth, yield and yield components of selected maize genotypes. Journal Agricultural Science 141:43-50.

Kranz WL, Irmak S, van Donk SJ, Yonts CD, Martin DL (2008). Irrigation management for corn. NebGuide G1850. University of Nebraska-Lincoln Extension. University of Nebraska- Lincoln Extension Bulletin No. G1850. Lincoln Neb. USA.

Liu H, Qi Z, Zhang PZ, Song WT, Kou J, Zhang WJ, Yu, JL (2012). Response of photosynthesis and chlorophyll fluorescence to drought stress in two maize cultivars. African Journal of Agricultural Research 7:4751-4760.

Lu M, Xie CX, Li XH, Hao ZF, Li MS, Weng JF, Zhang DG, Bai L, Zhang $\mathrm{SH}$ (2011). Mapping of quantitative trait loci for kernel row number in maize across seven environments. Molecular Breeding 28:143-152.

Lyimo SD, Massawe FA, Owenya MZ, Mushi P, Sulumo P (2001). Report presented to the National Seed Release Committee meeting held in November 2000 at Selian Agricultural Research Institute, Arusha, Tanzania: Selian Agricultural Research Institute.
Mafakheri A, Siosemardeh A, Bahramnejad B, Struik PC, Sohrabi Y (2010). Effect of drought stress on yield, proline and chlorophyll contents in three chickpea cultivars. Australian Journal of Crop Science 4:580-585.

Magehema OA, Ladislaus CB, Mkoma SL (2014). Implication of rainfall variability on maize production in Morogoro, Tanzania. International Journal of Environmental Science 5:1077-1086.

Monneveux P, Sanchez C, Beck D, Edmeades GO (2006). Drought tolerance improvement in tropical maize source populations: evidence of progress. Crop Science 46:180-191.

SAS Institute Inc. (2009). The SAS system for windows, Version 9.2. SAS Institute Inc. Cary, NC, USA.

Wei L, Zhang D, Xiang F, Zhang Z (2009). Differentially expressed miRNAs potentially involved in the regulation of defense mechanism to drought stress in maize seedlings. International Journal of Plant Science 170:979-989.

Xu J, Yuan Y, Xu Y, Zhang,G, Guo X, Wu F, Wang Q, Rong T, Pan G, Cao M, Tang Q, Gao S, Liu Y, Wang J, Lan H, Lu Y (2014). Identification of candidate genes for drought tolerance by whole genome resequencing in maize. BMC Plant Biology 14:83. 